\title{
SECRETION OF AN ALKALINE PROTEASE FROM A SALT- TOLERANT AND ALKALIPHILIC, STREPTOMYCES CLAVULIGERUS STRAIN MIT-1
}

\author{
Jignasha T. Thumar; Satya P. Singh* \\ Department of Biosciences, Saurashtra University, Rajkot, Gujarat, India.
}

Submitted: December 19, 2006; Returned to authors for corrections: April 02, 2007; Approved: November 19, 2007.

\begin{abstract}
An alkaliphilic and salt- tolerant actinomycete, Streptomyces clavuligerus strain Mit-1, was isolated from Mithapur, the western coast of India. The organism was Gram-positive, having filamentous, long thread like structure. The sporulation started after two days of growth and the optimum level of alkaline protease $(130 \mathrm{U} /$ $\mathrm{ml}$ ) was produced during the early stationary phase. The strain could grow and produce protease with $0-10 \%$ $\mathrm{NaCl}(\mathrm{w} / \mathrm{v})$, the optimum being $5 \% \mathrm{NaCl}(\mathrm{w} / \mathrm{v})$. Growth and protease production was optimum at $\mathrm{pH} 9$ with substantial decline at neutral $\mathrm{pH}$. Sucrose and gelatin were the best carbon and nitrogen sources respectively, whereas gelatin broth was the preferred medium for protease production. Mit-1 produced substantial protease with various amino acids, when employed as the sole nitrogen sources. Crude substrates, such as molasses, whey and wheat flour had significant effect on enzyme production. The results are quite valuable, as only few actinomycetes, particularly salt-tolerant alkaliphilic ones, have so far been explored for their enzymatic potential and process optimization.
\end{abstract}

Key words: Streptomyces clavuligerus, salt-tolerant actinomycetes, alkaline protease, enzymatic potential, protease optimization

\section{INTRODUCTION}

Besides antibiotics, enzymes are the bioactive compounds that have focused attention. The demand for microbial enzymes in industrial fields is increasing day by day due to their applications in clean, environment-friendly and cost effective biotechnological processes. The present global market for the industrial enzymes is around $\$ 2$ billion and expected to rise at an average annual growth rate of $3.3 \%$. But most of the enzymes are derived from microbes thriving in ambient temperature, neutral $\mathrm{pH}$ and other modest conditions. In view of the above realization, exploration of extremophiles and their biocatalytic machinery has been attracting the greater attention. Among the various groups of extremophiles, halo-tolerant/halophilic organisms are the major categories with greater biocatalytic potential $(17,32)$.

Proteases are among the most important class of industrial enzymes, which constitute $>65 \%$ of the total industrial applications, such as laundry detergent, leather preparation, meat tenderization and peptide synthesis (11). During last several years, few haloalkaliphilic bacteria have been studied for their ability to secrete alkaline protease $(5,13,16,26-28)$; however, alkaliphilic actinomycetes are relatively less explored in this context.

While most of the studies are concerned with the molecular phylogeny of halo-tolerant and alkaliphilic actinomyces $(6,10,14,18,19)$, the similar attention has not been paid to their enzymology. However, the ability to produce a variety of enzymes may be an attractive phenomenon in these prokaryotes. Recently, alkaline protease from Nocardiopsis sp. NCIM 5124 (8) has been purified and characterized. Similarly, an alkaline protease was purified and crystallized from Nesterenkoni sp. (2). Several species of the Streptomyces are among the most important industrial microorganisms because of their capacity to produce numerous bioactive molecules, particularly antibiotics and enzymes $(7,22)$. A

*Corresponding Author. Mailing address: Department of Biosciences, Saurashtra University, Rajkot - 360005, Gujarat, India. Tel.: + 912812586419.

E-mail: satyapsingh@yahoo.com 
keratinolytic serine proteinase was characterized from Streptomyces pactum DSM 40530 (4).

While there are few reports on the secretion of alkaline proteases from alkaliphilic actinomycetes, the studies on the factors affecting the production of the enzyme are rare. The investigations on salt- tolerant alkaliphilic actinomycetes with respect to their enzymatic potential are particularly limited. Thus, process optimization for the enzyme production from such organisms would be an alternative to traditionally used protease producers. Therefore, the present study aims at the factors that affect alkaline protease production from salt- tolerant alkaliphilic actinomycetes.

\section{MATERIALS AND METHODS}

\section{Microorganism}

A halo-tolerant and alkaliphilic actinomycete, Mit-1, identified as Streptomyces clavuligerus, was isolated from saline soil collected from coastal region of Mithapur, Gujarat, India. The saline soil $(10 \mathrm{~g})$ was incubated at $45^{\circ} \mathrm{C}$ with $\mathrm{CaCl}_{2}(1 \mathrm{~g})$ for one week. The treated soil was enriched in Actinomyces broth (Hi Media Ltd.) with $\mathrm{NaCl}(5 \%$, w/v). The $\mathrm{pH}$ of the medium was adjusted to 9 by adding separately sterilized $\mathrm{Na}_{2} \mathrm{CO}_{3}(20 \%$, w/v). The enriched culture was streaked on the Actinomyces agar (5\% w/v NaCl, pH 9). After the incubation of 6 days at $30^{\circ} \mathrm{C}$, a typical chalky white colony was picked up and re-streaked to ensure the purity of the colony. The organism was gram-positive, with filamentous structure. The organism was identified as Streptomyces clavuligerus based on the morphological, physiological and biochemical characteristics. The culture was assigned MTCC 7037 as accession/strain number by Microbial Type Culture Collection and Gene Bank, IMTECH, Chandigarh (India).

\section{Protease production in liquid culture medium}

Inoculum was prepared by transferring a loop full of culture from the slant into the $25 \mathrm{ml}$ of sterile gelatin broth containing $(\mathrm{g} / \mathrm{l})$ : gelatin, 10 ; peptone, 5 ; yeast extract, $5 ; \mathrm{NaCl}, 50$ and $\mathrm{pH} 9$. The inoculum was incubated at $30^{\circ} \mathrm{C}$ on a rotary shaker $(100$ $\mathrm{rpm}$ ) for $48 \mathrm{~h}$. The inoculum at $10 \%$ was added into the gelatin broth followed by incubation at $30^{\circ} \mathrm{C}$ under shaking conditions. After the incubation for $110 \mathrm{~h}$, the cultures were harvested and mixed to homogeneity by Vortex mixer followed by measurement of growth at $540 \mathrm{~nm}$. The crude enzyme was harvested by filtration with cellulose filter and the filtrate was used as crude enzyme preparation.

\section{Enzyme Assay}

The enzyme was assayed by the Anson- Hagihara method (12) using casein as a substrate. One unit of alkaline protease activity (U) was taken as the amount of enzyme liberating $1 \mu \mathrm{g}$ of tyrosine per min under the assay conditions. The estimations were based on a tyrosine calibration curve.

\section{Growth kinetics of Mit-1 with reference to protease production}

After activation in sterile gelatin broth $(5 \% \mathrm{w} / \mathrm{v} \mathrm{NaCl}, \mathrm{pH} 9)$, $10 \%$ of inoculum was added into the gelatin broth and incubated at $30^{\circ} \mathrm{C}$ under shaking conditions (100 rpm). Cultures were withdrawn aseptically at $6 \mathrm{~h}$ interval and growth and enzyme activity were monitored as described above.

\section{Effect of media on growth and protease production}

The growth and protease production was compared in different media such as gelatin, starch, complete medium, gelatin casaminoacid, glucose asparagine, starch casein, glycerol asparagine, glycerol glycine and Actinomyces broth. The culture media after inoculation were incubated at $30^{\circ} \mathrm{C}$ under shake flask conditions for $110 \mathrm{~h}$ followed by the measurement of growth and protease production.

\section{Effect of NaCland pH}

The effect of $\mathrm{NaCl}$ on protease production was carried out in gelatin broth at varying concentrations of salt $(0-10 \%, w / v)$ at $\mathrm{pH}$ 9. The growth and enzyme activity were monitored after $110 \mathrm{~h}$ of growth under shaking conditions. Similarly, the growth and enzyme production were also monitored at $\mathrm{pH}$ in the range of $7-10$ with $5 \%$ w/v NaCl.

\section{Effect of cations on protease production}

Different salts; $\mathrm{CaCl}_{2}, \mathrm{MgCl}_{2} \cdot 7 \mathrm{H}_{2} \mathrm{O}, \mathrm{MnCl}_{2}$ and $\mathrm{KCl}$ were included in gelatin broth at the concentration of $0.5 \%, \mathrm{w} / \mathrm{v}$ for $\mathrm{Ca}^{++}, \mathrm{Mg}^{++}, \mathrm{Mn}^{++}$and $\mathrm{K}^{+}$respectively. After the incubation of $110 \mathrm{~h}$, growth and protease secretion were measured.

\section{Effect of carbon and nitrogen sources}

In order to study the effect of carbon sources on protease production, gelatin broth was supplemented with various sugars viz. xylose, glucose, maltose, lactose, sucrose and starch at $1 \%$ $(\mathrm{w} / \mathrm{v})$. After $110 \mathrm{~h}$ growth at $30^{\circ} \mathrm{C}$ under shaking conditions, growth and protease activity were measured.

Correspondingly, various organic and inorganic nitrogen sources were investigated for their effect on the growth and protease production. The organic nitrogen sources were gelatin, casein, peptone and yeast extract, while inorganic nitrogen sources included ammonium nitrate, ammonium oxalate, ammonium sulphate, ammonium molybdate and ammonium acetate; all at $1 \%(\mathrm{w} / \mathrm{v})$. The respective nitrogen sources were included as the sole source of nitrogen in minimal medium $(5 \% \mathrm{NaCl}, \mathrm{w} / \mathrm{v}, \mathrm{pH}$ 9), which contained; solution $\mathrm{A}$ $(800 \mathrm{ml})+$ solution B $(200 \mathrm{ml})$. Solution A included (g/l): $\mathrm{KH}_{2} \mathrm{PO}_{4}$, $3 ; \mathrm{Na}_{2} \mathrm{HPO}_{4}, 6 ; \mathrm{NH}_{4} \mathrm{Cl}, 2 ; \mathrm{NaCl} ; 50$. Solution $\mathrm{B}$ contained $(\mathrm{g} / \mathrm{l})$ : glucose, $8 ; \mathrm{MgSO}_{4} \cdot 7 \mathrm{H}_{2} \mathrm{O}, 0.1$. The culture media after inoculation were incubated at $30^{\circ} \mathrm{C}$ for $110 \mathrm{~h}$ under shake flask conditions followed by the estimation of growth and protease activity. 


\section{Protease production with amino acids as the sole source of nitrogen}

Experiments were designed to investigate the effect of amino acids as the sole nitrogen source. Methionine, alanine, histidine, tyrosine, arginine, phenylalanine, aspartic acid and leucine were selected from the five classes of amino acids based on the polarity and $\mathrm{R}$ group. The respective amino acids, at the concentration of $1 \% \mathrm{w} / \mathrm{v}$, were included in minimal medium $(5 \%, \mathrm{w} / \mathrm{v}, \mathrm{NaCl}, \mathrm{pH} 9)$. Incubation was carried out at $30^{\circ} \mathrm{C}$ for $110 \mathrm{~h}$ under shaking conditions followed by the measurement of growth and protease activity.

\section{Protease production with crude sources}

Molasses and whey in the range of $0-2 \% \mathrm{v} / \mathrm{v}$ and wheat flour in the range of $0-2 \% \mathrm{w} / \mathrm{v}$ were included in minimal medium $(5 \% \mathrm{w} / \mathrm{v} \mathrm{NaCl}$ and $\mathrm{pH} 9)$ as the sole source of both, carbon and nitrogen. After the incubation of $110 \mathrm{~h}$ at $30^{\circ} \mathrm{C}$, the culture samples were withdrawn and monitored for growth and enzyme activity.

All the experiments described have been done in triplicates and average values are presented in the results.

\section{RESULTS AND DISCUSSION}

The present study relates to the production and optimization of an alkaline protease from a halo-tolerant, alkaliphilic actinomycete. The growth kinetics of Mit-1 was followed up to $156 \mathrm{~h}$ in gelatin broth $(5 \% \mathrm{w} / \mathrm{v}, \mathrm{NaCl}, \mathrm{pH} 9)$. The organism entered in the exponential phase after $26 \mathrm{~h}$ that continued up to $100 \mathrm{~h}$ followed by stationary phase (Fig. 1). Protease production was optimum at $110 \mathrm{~h}(130 \mathrm{U} / \mathrm{ml})$ during early stationary phase (Fig. 1). This result is in agreement with Bascaran et al., (3) and Moreira et al., (25), who showed that synthesis of protease from Streptomyces clavuligerus starts in the early stationary phase of growth. Similarly, in Streptomyces rimosus, the optimum protease production was recorded at $166 \mathrm{~h} \mathrm{(36).}$

The study on enzymes usually involves a search for optimal media for their production. The comparative production of enzyme in different media revealed that while growth was nearly similar, the enzyme production varied. While the growth of Mit1 was optimum in Actinomyces broth, the enzyme production was optimum $(135 \mathrm{U} / \mathrm{ml})$ in the gelatin broth, which may be due to induction of enzyme secretion by peptone and gelatin (Fig. 2). In Streptomyces clavuligerus, the enzyme production varied greatly with the culture media used (30). Recently, a newly isolated haloalkaliphilic Bacillus sp. was reported to produce optimum level of alkaline protease in gelatin broth (29).

Salt had pronounced effect on growth and enzyme production. Mit-1 grew up to $10 \% \mathrm{w} / \mathrm{v}$ salt, the optimum being at $5 \% \mathrm{w} / \mathrm{v}$, which is quite similar to that of Nocardiopsis kunsanensis sp. nov., a moderately halophilic actinomycete (6). Similarly, Kocuria marina sp. nov., a novel actinomycete,

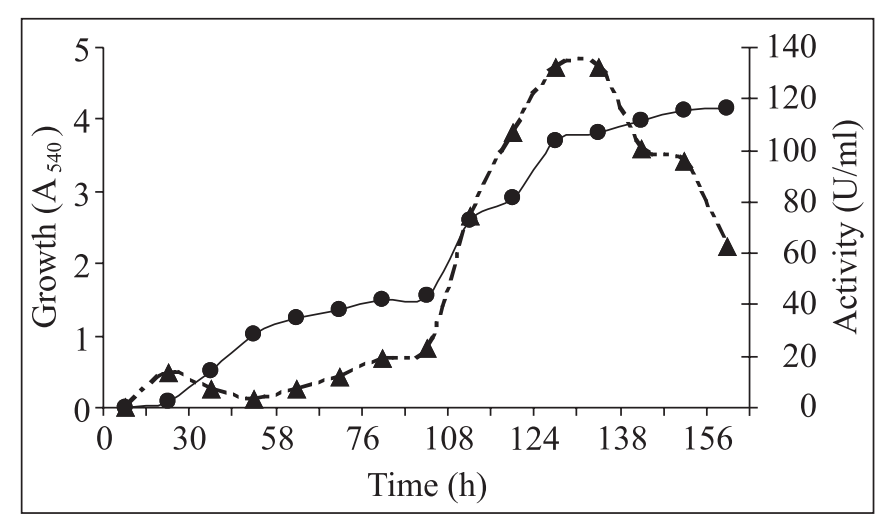

Figure 1. Growth kinetics of Mit-1 with references to protease production by Streptomyces clavuligerus. Growth $\left(\lambda_{540}\right)$ and protease activity $(\mathbf{\Delta})$.

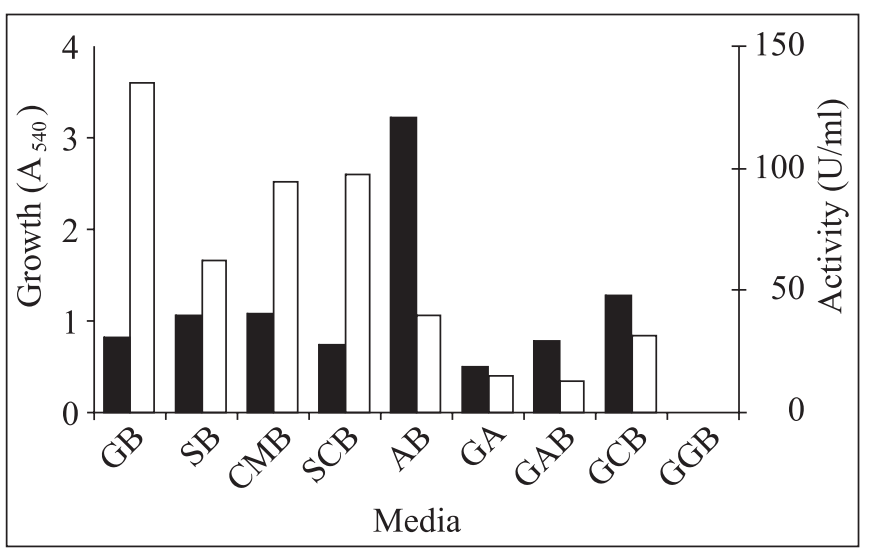

Figure 2. Effect of various media on growth ( $\mathbf{\square})$ and protease production ( $\square$ ) in Streptomyces clavuligerus. GB: Gelatin Broth, SB: Starch Broth, CMB: Complete Medium Broth, SCB: Starch Casein Broth, AB: Actinomyces Broth, GAA: Glucose Asparagine Broth, GAB: Glycerol Asparagine Broth, GCB: Gelatin Casaminoacid broth, GGB: Glycerol Glycine Broth.

tolerated up to $15 \% \mathrm{NaCl}$ in growth media, although its presence was not essential for growth (18). Mit-1 was also capable to grow with $0 \%$ salt indicating the halo-tolerant nature of the organism (Fig. 3). The protease production was optimum (158 $\mathrm{U} / \mathrm{ml}$ ) with $5 \% \mathrm{w} / \mathrm{v} \mathrm{NaCl}$ with a sharp decrease at $10 \%$. The salt requirement of our isolate, however, was much less compared to Streptomonospora alba sp. nov., a truly halophilic actinomycete (20).

The effect of $\mathrm{pH}$ was investigated on growth and enzyme production. Mit-1 grew optimally at $\mathrm{pH} 9$ with slow growth at neutral pH (Fig. 4). Recently, a novel alkaliphilic actinomycetes Streptomyces sodiiphilus sp. nov. was reported to grow with 


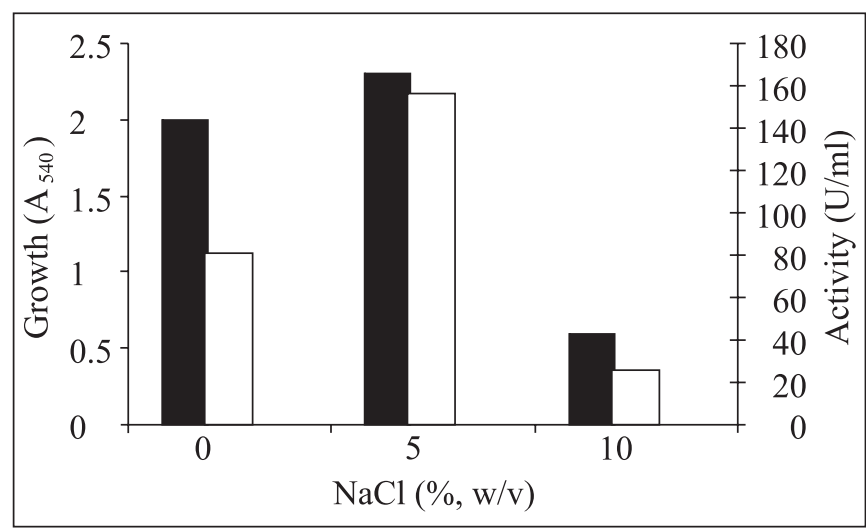

Figure 3. Effect of salt on growth ( $(\mathbf{\square})$ and protease production $(\square)$ in Streptomyces clavuligerus.

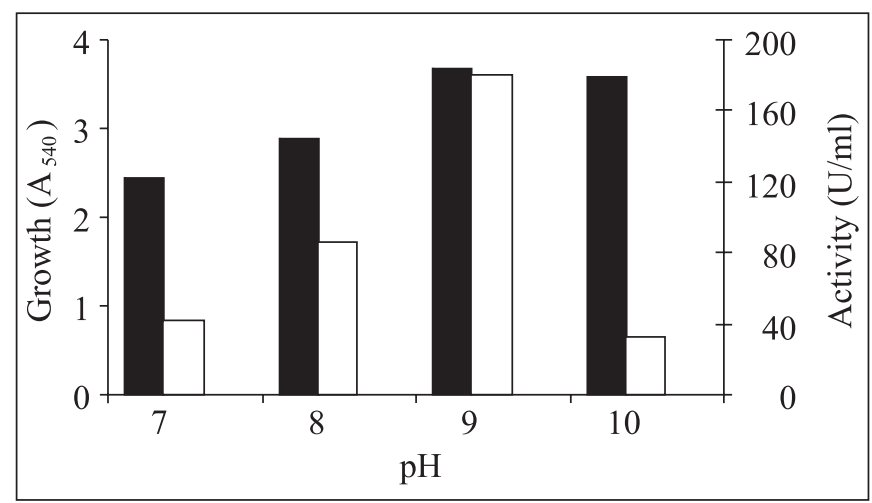

Figure 4. Effect of $\mathrm{pH}$ on growth $(\boldsymbol{\square})$ and protease production $(\square)$ in Streptomyces clavuligerus.

an optimum $\mathrm{pH}$ of $9-10$ with scant growth at $\mathrm{pH} 7$ (21). Similarly, Nocardiopsis alkaliphila also grew optimally at $\mathrm{pH}$ 9.5-10 (14). Mit-1 displayed optimum protease activity $(180 \mathrm{U} / \mathrm{ml})$ at $\mathrm{pH}$ 9. Although the growth was almost similar at $\mathrm{pH} 9$ and 10 , protease production varied greatly. The enzyme secretion was adversely affected at lower $\mathrm{pH}$ compared to that at $\mathrm{pH} 10$, confirming the alkaliphilic nature of the enzyme. Similar response has also been observed in alkaliphilic Nocardiopsis sp. TOA-1 in which alkaline protease was produced optimally at $\mathrm{pH}$ 9-10 (24).

In general, cations are known to induce enzyme secretion and increase the thermo stability of the enzyme (33). While growth was optimum with $\mathrm{Ca}^{2+}$ and $\mathrm{Mg}^{2+}$, the organism secreted alkaline protease optimally $(310 \mathrm{U} / \mathrm{ml})$ with $\mathrm{Mg}^{2+}$ (Fig. 5). The enzyme production was comparable with $\mathrm{Ca}^{2+}$ and $\mathrm{K}^{+}$, and was completely suppressed with $\mathrm{Mn}^{2+}$. The results are similar to those from Streptomyces rimosus where calcium carbonate enhanced protease production (35).
Various sugars were investigated for their effect on protease production. Glucose was the best carbon source for growth whereas protease production was optimum with sucrose $(410$ $\mathrm{U} / \mathrm{ml}$ ). While other sugars, such as maltose, xylose, lactose, glucose, supported protease production; starch affected it adversely (Fig. 6). Contrary to our results, in Streptomyces rimosus, protease production was optimum with starch (35).

In most microorganisms, the nitrogen source (both organic and inorganic forms) is metabolized to produce primarily amino acids, nucleic acids, proteins and cell wall components. Alkaline protease is comprised of $15.6 \%$ nitrogen and its production depends heavily on the availability of nitrogen sources in the medium. In our study, the growth, as compared to enzyme production, was marginally affected by organic nitrogen sources. Protease production was optimum with gelatin (100 U/ $\mathrm{ml})$ and peptone $(100 \mathrm{U} / \mathrm{ml})$ followed by yeast extract and casein (Fig. 7). Although a reduced growth was observed with yeast extract, protease production was enhanced significantly in its

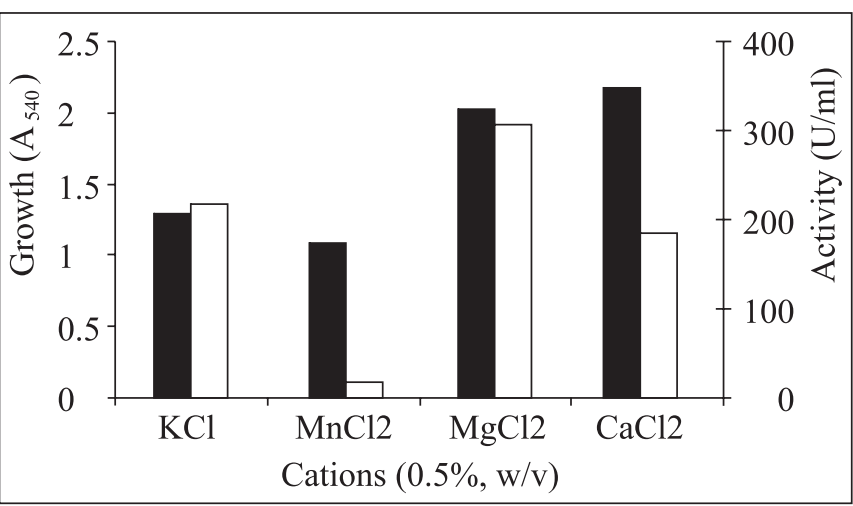

Figure 5. Effect of cations $(0.5 \%)$ on growth $(\boldsymbol{\square})$ and protease production $(\square)$ in Streptomyces clavuligerus.

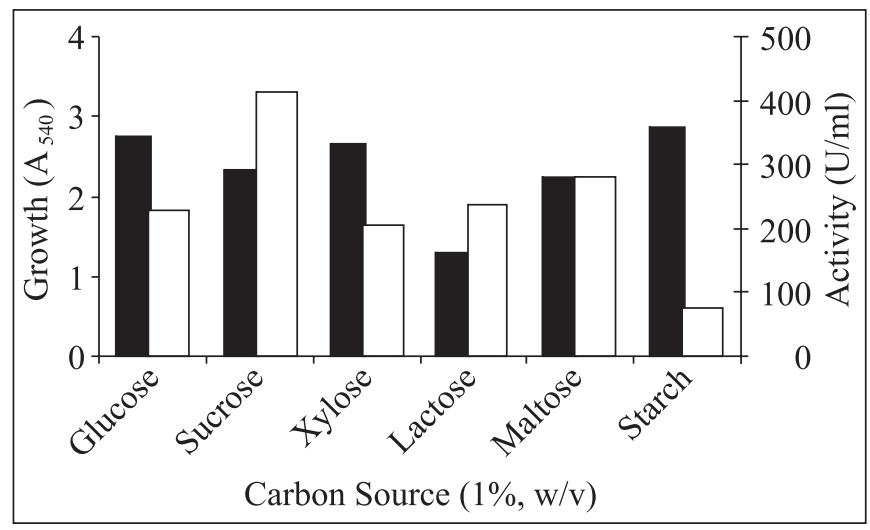

Figure 6. Effect of carbon sources on growth $(\boldsymbol{\square})$ and protease production $(\square)$ in Streptomyces clavuligerus. 
presence. Similarly, Nocardiopsis metallicus sp. nov., a metalleaching actinomycete, has been reported to utilize various organic nitrogen sources for growth and enzyme production (31).

In the presence of inorganic nitrogen sources such as ammonium nitrate, ammonium sulfate, ammonium molybdate, ammonium oxalate and ammonium acetate, the growth and enzyme production were adversely affected as compared to organic nitrogen supplements. Among the inorganic nitrogen sources, however, ammonium nitrate emerged as the best in supporting enzyme production (100 U/ml) (Fig. 8). Yang and Lee (35) reported ammonium sulphate as the best nitrogen source for protease production in Streptomyces rimosus. Interestingly, in Streptomyces cremeus, the enzyme production was not supported by any single nitrogen source, instead a combination of peptone, soy flour and ammonium sulphate was most suitable (34).

Amino acids are known to induce protease production (23). Growth and protease production greatly vary in response to different amino acids. Among the amino acids employed, asparagine was the best for growth; however, it did not support

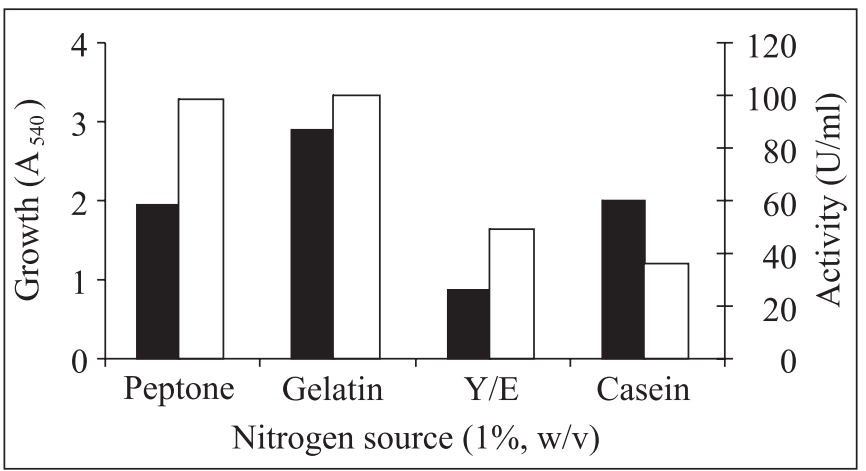

Figure 7. Effect of various organic nitrogen sources on growth (ם) and protease production ( $\square$ ) in Streptomyces clavuligerus.

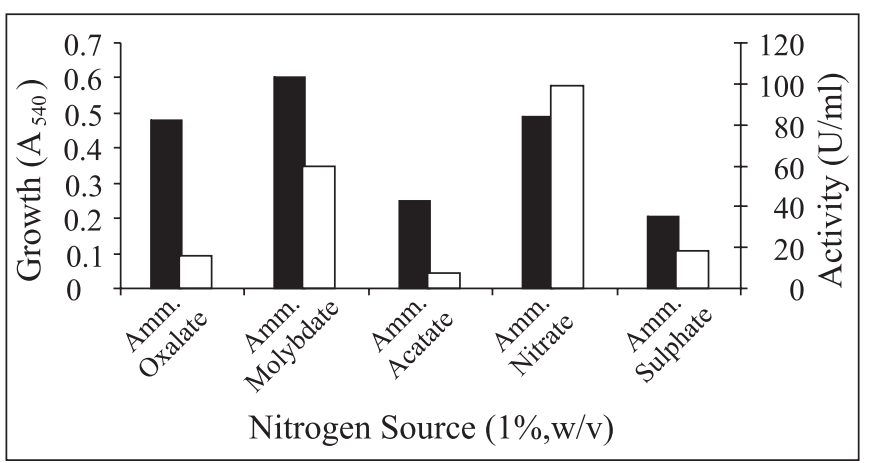

Figure 8. Effect of various inorganic nitrogen sources on growth $(\square)$ and protease production ( $\square$ ) in Streptomyces clavuligerus. the enzyme production at all. Significant growth was also evident with arginine and phenylalanine (Fig. 9). Although the growth was quite less, the protease production was optimum with leucine $(130 \mathrm{U} / \mathrm{ml})$. The leucine supported protease production was quite comparable to those obtained with complex media. Except histidine and phenylalanine, protease production was significantly retarded in the presence of other amino acids. The results are comparable to a neutrophilic Streptomyces clavuligerus that was capable to grow with asparagine and glutamine (1). Similarly, Streptomyces pristinaespiralis has also been reported to use alanine and glutamate as the sole source of nitrogen (9). Bascaran et al., (3) stated that better protease production could be obtained with nitrogen-free medium or poorly utilized amino acids.

Among various cheap sources, industrial by-products such as molasses and other cheaper components like whey and wheat flour have focused considerable attention, as they support both cell mass and enzyme production (17). The crude sources, employed in the present study, supported growth and protease synthesis significantly. Molasses, when used as the sole carbon and nitrogen source, induced protease production up to $1 \% \mathrm{v} / \mathrm{v}$ above which it gradually repressed (Fig. 10). Apart from molasses, wheat flour (1.5\%, w/v, Fig. 11) and whey (1-1.5\%, v/v, Fig. 12) also enhanced the enzyme level significantly. These findings are in agreement with an alkaline protease from Bacillus JB 99 (15). The ability of the organism in this study to grow and produce enzyme with amino acids as well as cheaper agro-industrial by-products assumes significance. The production of the enzyme with these sources would be economically attractive prepositions. Besides, the regulation of enzyme synthesis in response to various carbon and nitrogen sources would be interesting to investigate further.

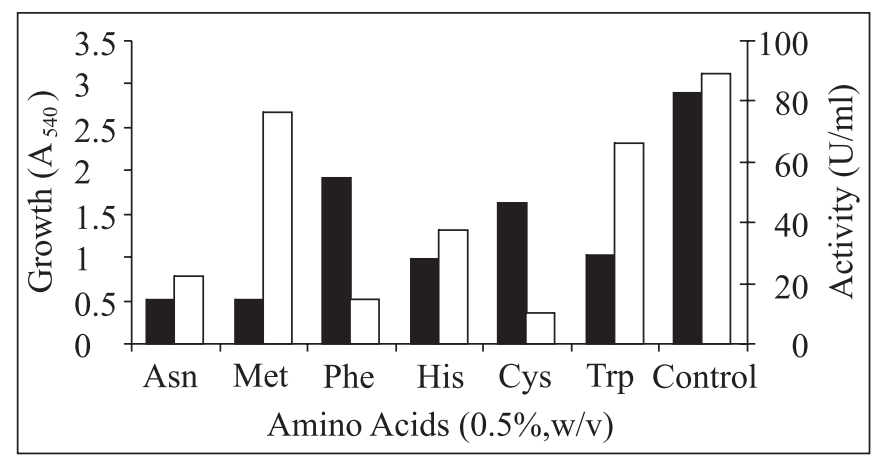

Figure 9. Protease production on amino acids as the sole source of nitrogen. Growth ( $\boldsymbol{\square})$ and protease production $(\square)$ in Streptomyces clavuligerus. Met: Methionine; Ala: Alanine; His: Histidine; Tyr: Tyrosine; Phe: Phenylalanine; Arg: Arginine; Leu: Leucine; Asn: Asparagine. 


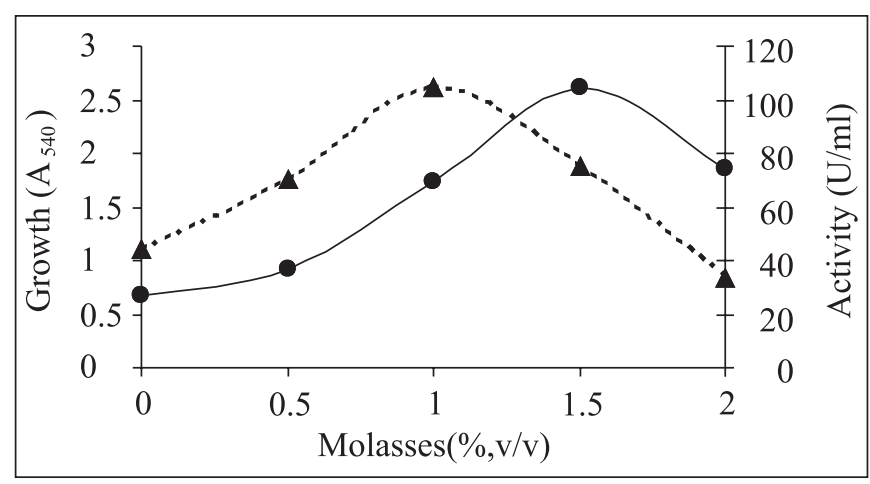

Figure 10. Effect of molasses on growth (O) and protease production ( $\mathbf{\Delta})$ in Streptomyces clavuligerus.

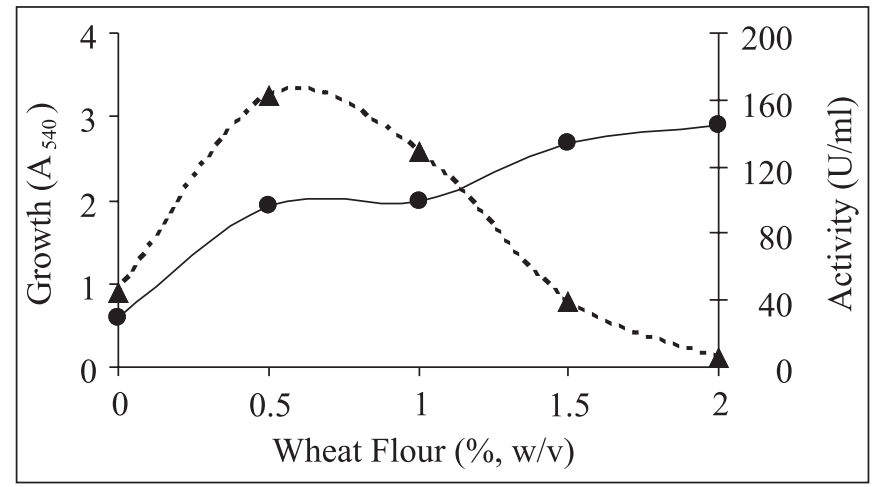

Figure 11. Effect of wheat flour on growth (O) and protease production ( $\mathbf{\Delta})$ in Streptomyces clavuligerus.

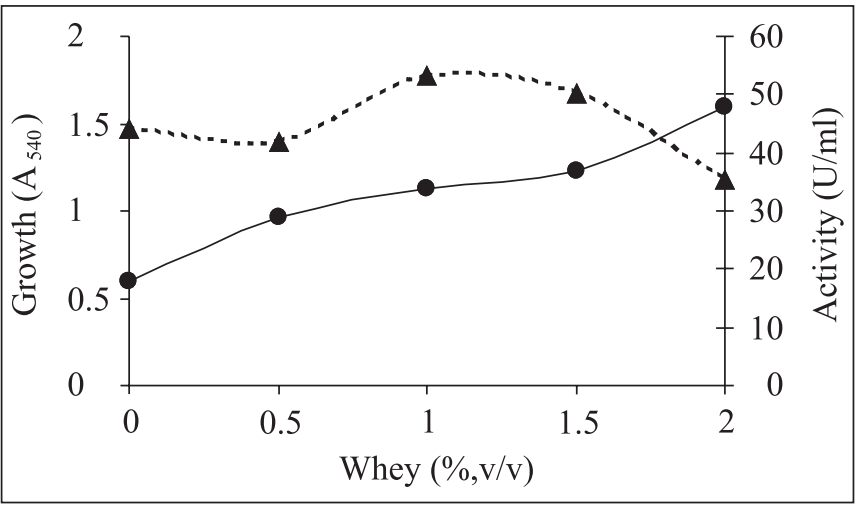

Figure 12. Effect of whey on growth ( $)$ and protease production ( $\mathbf{\Delta})$ in Streptomyces clavuligerus.

\section{ACKNOWLEDGEMENT}

Financial Assistance from University Grants Commission (New Delhi, India) and Saurashtra University, Rajkot (India) is acknowledged.
Production of the enzyme at large scale is an important step to realize the actual potential of the organisms. However, the remarkable opportunities that the uncommon and relatively less explored actinomycetes present for biotechnological applications might not be realistic in actual economic sense. The results describe the optimization of the parameters for alkaline protease production at lab-scale in a salt-tolerant and alkaliphilic Streptomyces clavuligerus. The organism produced protease optimally with $5 \% \mathrm{w} / \mathrm{v} \mathrm{NaCl}$ at $\mathrm{pH} 9$ during early stationary phase in the gelatin broth. Organic nitrogen sources were better for growth and enzyme production compared to inorganic ones. The growth and protease secretion with molasses, whey and wheat flour - the cheaper carbon and nitrogen sources, appear to be a commercially attractive feature. The results in general reflect on the enzymatic potential and its optimization among the relatively less explored group of actinomycetes.

\section{RESUMO}

\section{Secreção de uma protease alcalina por uma cepa halotolerante e alcalifílica de Streptomyces clavuligerus, Mit-1}

Uma cepa halotolerante e alcalifílica de Streptomyces clavuligerus, Mit-1, foi isolada em Mithapur, na costa oeste da Índia. Esse microrganismo é Gram positivo e apresenta estrutura filamentosa na forma de longas cordas. A esporulação iniciou após dois dias de cultivo e o nível ótimo de produção de protease alcalina $(130 \mathrm{U} / \mathrm{ml})$ foi atingido no início da fase estacionária de crescimento. A cepa foi capaz de multiplicar com $0-10 \% \mathrm{NaCl}$ (w/v), com um ótimo de $5 \% \mathrm{NaCl}(\mathrm{w} / \mathrm{v})$. O ótimo de crescimento e produção de protease foi atingido em $\mathrm{pH}$ 9, apresentando declínio substancial em $\mathrm{pH}$ neutro. Sacarose e gelatina foram as melhores fones de carbono e nitrogênio, respectivamente, enquanto o caldo gelatina foi o melhor meio para produção de protease. A cepa Mit-1 produziu bastante protease quando vários aminoácidos foram empregados como única fonte de nitrogênio. Substratos crus, como melaço, soro de leite e farinha de trigo, tiveram um efeito significativo na produção da enzima. Os resultados são bastante interessantes, considerando que somente poucos actinomicetos, especialmente os halotolerantes, já foram explorados por seu potencial de produção de enzimas e otimização de processos.

Palavras-chave: Streptomyces clavuligerus, actinomicetos halotolerantes, protease alcalina, potencial enzimático, otimização de protease

\section{REFERENCES}

1. Aharonowitz, Y.; Demain, A.L. (1979). Nitrogen nutrition and regulation of cephalosporin production in Streptomyces clavuligerus. Can. J. Microbiol., 25: 61-67. 
2. Bakhtiar, S.; Vevodova, J.; Hatti-Kaul, R.; Su, X.D. (2003). Crystallization and preliminary X-ray analysis of an alkaline serine protease from Nesterenkonia sp. Acta. Crystallgr. D. Biol. Crystallogr., $59,529-31$

3. Bascaran, V.; Hardisson, C.; Brana, A.F. (1990). Regulation of extracellular protease production in Streptomyces clavuligerus. Appl. Microbiol. Biotechnol., 34, 208-213.

4. Bockle, B.; Galunsky, B.; Muller, R. (1995). Characterization of a keratinolytic serine proteinase from Streptomyces pactum DSM 40530. Appl. Environ. Microbiol., 61, 3705-3710.

5. Chaphalkar, S.R.; Deys. (1998). Thermostable alkaline mettalloprotease from newly isolated alkaliphilic Streptomyces diastaticus Strain SSI. Indian J. Bichem. Biophys., 35, 34-40.

6. Chun, J.; Bae, K.S.; Moon, E.Y.; Jung, S.O.; Lee, H.K.; Kim, S.J. (2000). Nocardiopsis kunsanensis sp. nov., a moderately halophilic actinomycete isolated from a saltern. Int. J. Syst. Evol. Microbiol., $5,1909-13$.

7. Dietera, A.; Hamm, A.; Fiedler, H.P.; Goodfellow, M.; Muller, W.E.; Brun, R.; Bringmann, G. (2003). Pyrocoll, an antibiotic, antiparasitic and antitumor compound produced by a novel alkaliphilic Streptomyces strain. J. Antibiot., 56, 639-46.

8. Dixit, V.S.; Pant, A. (2000). Comparative characterization of two serine endopeptidases from Nocardiopsis sp. NCIM 5124. BBA, 1523, 261-268.

9. Francois, V.; Stephane, A. (2001). Nitrogen source governs the patterns of growth and pristinamycin production in Streptomyces pristinaespiralis. Microbiology, 147, 2447-2459.

10. Groth, I.; Schumann, P.; Rajney, F.A.; Martin, K.; Schuetze, B.; Augsten, K. (1997). Bogoriella caseilytica gen. nov., sp. nov., a new alkaliphilic actinomycete from a soda lake in Africa. Int. J. Syst. Evol. Microbiol., 47, 788-794.

11. Gupta, M.N.; Roy, I. (2002). Applied Biocatalysts: An overview. Ind. J. Biochem. Biophys., 39, 220-228.

12. Hagihara, B. (1958). The Enzymes, Vol., 4 academic press Inc., New York.

13. Horikoshi, K. (1971). Production of alkaline enzymes by alkaliphilic microorganisms. I. Alkaline protease produced by Bacillus no. 221. Agric. Biol. Chem., 35, 1407-1414.

14. Hozzein, W.N.; Li, W.J.; Mohammed, I.A.; Hammouda, O.; Ahmed, S.M.; Li, H.X.; Jiang, C.L. (2004). Nocardiopsis alkaliphila sp. nov., a novel alkaliphilic actinomycetes isolated from desert soil in Egypt. Int. J. Syst. Evol. Microbiol., 54, 247-252.

15. Johnvesly, B.; Naik, G.R. (2001). Studies on production of thermostable alkaline protease from thermophilic and alkaliphilic Bacillus sp. JB-99 in a chemically defined medium. Process Biochem. 37,139-144.

16. Jones, C.W.; Morgan, H.W.; Danial, R.M. (1988). Aspects of protease production by Thermus strain OK6 and other New Zealand isolates. Gen. Microbiol., 134, 191-198.

17. Kanekar, P.P.; Nilegaonkar, S.S.; Sarnaik, S.S.; Kelkar, A.S. (2002). Optimization of protease activity of alkaliphilic bacteria isolated from an alkaline lake in India. Biores. Technol., 85(1), 87-93.

18. Kim, S.B.; Nedashkovskaya, O.I.; Mikhailov, V.V.; Han, S.K.; Kim, K.O.; Rhee, M.S.; Bae, K.S. (2004). Kocuria marina sp. nov., a novel actinobacterium isolated from marine sediment. Int. J. Syst. Evol. Microbiol., 54, 1617-20.

19. Li, W.J.; Xu, P.; Tang, S.K.; Li, Xu; Reiner, M.; Kroppenstedt, A.; Stackebrandt, E.; Jiang, C.L. (2003). Prauserella halophila sp. nov. and Prauserella alba sp. nov., moderately halophilic actinomycetes from saline soil. Int. J. Syst. Evol. Microbiol., 53, 1545-1549.
20. Li, W.J.; Xu, P.; Zhang L.P.; Tang, S.K.; Cui, X.L.; Mao P.H.; Xu, L.H.; Schumann, P.; Stackebrandt, E.; Jiang, C.L. (2003). Streptomonospora alba sp. nov., a novel halophilic actinomycete, and emended description of the genus Streptomonospora. Int. J. Syst. Evol. Microbiol., 53, 1421-1425.

21. Li, W.J.; Zhang, Y.G.; Zhang, Y.Q.; Tang, S.K.; Xu, P.; Li, H.X.; Jiang, C.L. (2005). Streptomyces sodiiphilus sp. nov., a novel alkaliphilic actinomycete. Int. J. Syst. Evol. Microbiol., 55, 1329-1333.

22. Manam, R.R.; Teisa, S.; White, D.J.; Nicholson, B.; Neuteboom, S.T.; lam, K.S.; Mosca, D.A.; Lloyd, G.K.; Potts, B.C. (2005). Lajollamycin, a nitro-tetraenespiro-beta-lactone-gamma-lactum antibiotic from the marine actinomycetes Streptomyces nodosus. J. Nat. Prod., 68, 240-3.

23. McDonald, I.J.; Chambers,A. (1966). Regulation of proteolytic enzyme production in a species of Micrococcus. Canad. J. Microbiol., 12, 1175-1185.

24. Mitsuiki, S.; Sakai, M.; Moriyama, Y.; Goto, M.; Furukawa, K. (2002). Purification and some properties of a keratinolytic enzyme from an alkaliphilic Nocardiopsis sp. TOA-1. Biosci. Biotech. Biochem., 66, 164-7.

25. Moreira, K.A.; Cavalcanti, M.T.; Duarte, H.S.; Tambourgi, E.B.; Silva, V.L.; Porto, A.L.; Filho, J.L. (2001). Partial characterization of proteases from streptomyces clavuligerus using an inexpensive medium. Braz. J. Microbiol., 32, 23-28.

26. Nascimento, W.C.; Martins, M.L. (2004). Production and properties of an extracellular protease from thermophilic Bacillus sp. Braz. J. Microbiol., 35, 1-2.

27. Niehaus, F.; Bertoldo, C.; Kahler, M.; Antranikian, G. (1999). Extremophiles as a source of novel enzymes for industrial application. Appl. Microbiol. Biotechnol., 51, 711-729.

28. Nomoto, M.; Lee, T-C.; Su, C-S.; Liao, C-W.; Yen, T.M.; Yang, C.P. (1984). Alkaline proteinases from alkaliphilic bacteria of Taiwan. Agric. Biol. Chem., 48, 1627-1628.

29. Patel, R.K.; Dodia, M.S.; Singh, S.P. (2005). Extracellular alkaline protease from a newly isolated haloalkaliphilic Bacillus sp.: Production and optimization. Process Biochem., 40, 3569-3575.

30. Porto, A.L.; Campos-Takaki, G.M.; Lima, J.L. (1996). Effects of culture conditions on protease production by Streptomyces clavuligerus growing on soy bean flour medium. Appl. Biochem. Biotech., 60, 115-122.

31. Schippers, A.; Bosecker, K.; Willscher, S.; Sproer, C.; Schumann, P.; Kroppenstedt, R.M. (2002). Nocardiopsis metallicus sp. nov., a metal-leaching actinomycete isolated from an alkaline slag dump. Int. J. Syst. Evol. Microbiol., 52, 2291-5.

32. Setyorini, E.; Takenaka, S.; Murakami, S., Aoki, K. (2006). Purification and characterization of two novel halotolerant extracellular proteases from Bacillus subtilis strain FP-133. Biosci. Biotechnol. Biochem., 70(2), 433-440.

33. Sinha, R. (1993). Purification and characterization of Bacillus alkaline protease. M.Sc. Thesis, G.B. Pant Uni. Of Agriculture and Technology, Pantnagar.

34. Vinogrodova, K.A.; Vlasova, I.I.; Sharkova, T.S.; Dodzin, M.E.; Maksimov, V.N. (2003). L-Glutamate oxidase from Streptomyces cremeus 510 MGU: effect of nitrogen sources on enzyme secretion. Antibiot. Khimioter., 48, 3-8.

35. Yang, S.; Lee, C. (2001). Effect of culture media on protease and oxytetracycline productin with mycelium and protoplasts of Streptomyces rimosus. World J. Microbiol. Biotechnol., 17, 403-410.

36. Yang, S.S.; Wang, J.Y. (1999). Protease and amylase production of Streptomyces rimosus in submerged and solid state cultivations. Bot. Bull. Acad. Sin., 40: 259-265. 